\title{
Globalization and its impact on employee motivation
}

\author{
Katarina Stalmachova ${ }^{1, *}$, and Mariana Strenitzerova ${ }^{1}$ \\ ${ }^{1}$ University of Žilina, Faculty of Operation and Economics of Transport and Communications, \\ Department of Communications, Univerzitná 1, 01026 Žilina, Slovakia
}

\begin{abstract}
.
Research background: The globalization affects the labour requirements. Therefore, it is important to distinguish, for example, the composition of the workforce in terms of age. The ageing population is a global problem and labour shortages in the labour market force employers to address the diversity of the age structure of their current as well as potential employees.

Purpose of the article: The goal of the article is to compare the importance of motivational factors of different age groups of employees. The conclusion of the article also compares the significance of factors in terms of the age structure of employees.

Methods: In the article, the method of analysis of available resources was used. Then the method of synthesis was used in finding out the connection between the resources. The sample of employees is divided into groups according to age categories. By using factor analysis, the factors affecting them are identified for each age group of employees. Primary research, as a basis for factor analysis, was carried out using a questionnaire.

Findings \& Value added: Motivation is one of the key elements of human resource management. It can contribute to increasing employee performance and satisfaction. It is essential to the effective functioning of each organization and achievement of strategic goals. By knowing the preferences and values of employees, the article can bring recommendations for improving the current motivation systems in organizations. This can contribute to the efficient use of employers' money they spend on employee benefits.
\end{abstract}

Keywords: globalization, motivation, human resource, ageing population

JEL Classification: $J 30, J 45, J 50$

\section{Introduction}

Today's world is characterized by globalization; development is accelerating and labour and technology markets are rapidly changing [1]. In general, the concept of globalization

\footnotetext{
*Corresponding author: katarina.stalmachova@,fpedas.uniza.sk
} 
can be understood as a fact that different cultures and economic systems around the world are becoming connected and similar to each other. This also applies to human resource management. From a global perspective, digital technologies may have an impact on the employment and unemployment in labour market. [2]. For deciding firms' choice of human resources management practices, increasing competition due to globalization is a substantial factor [3]. In today's competitive environment and global world, where the boundaries have disappeared as a result of the continuous development in communication and technology, the attitudes and behaviours of the employees in their organizations are becoming more important [4]. According to Khan, globalization has a strong impact on formal motivational and strategic human resource practices. Globalization not only changes structural boundaries, but it has also influenced the content of human resource management [5]. It can be stated, that the world is more interconnected than ever before. Traditional leadership roles and traditional ways of managing people need to adapt to changing times. Interconnectedness is linked to rapid response, greater global reach, and electronic-based forms of communication [6]. Employees are increasingly becoming the most important asset of the organization. Employers need to understand the complexities of their workforce and how to maximize its potential [7]. They realize that properly motivated and satisfied employees can ensure the organization's long-term prosperity and efficient operation.

\subsection{Aging population and age diversity of the workforce}

Nowadays, the demographic development is an important factor that affects the functioning of society as a whole. In the Slovak Republic, it is characterized by a gradual slowdown and significant changes in the age composition of the population. Retirement was once considered an exit from full-time work into full-time leisure. Research evidence indicates, that a growing number of retirees are re-entering the labour force [8]. According to the Demographic Challenge for the next decades in Slovakia, the number of people of working age will decrease significantly by 2060 . The decline will affect the population in both younger and older productive ages; therefore, the average age of the productive population will not change significantly (it will move close to the 43-year limit). Significant reduction in the number and share of people in the productive age is an important and direct signal especially for the labour market. However, there are many other impacts that society must prepare for. Significant population decrease at a younger productive age will have a significant demographic impact. The number of children born will decrease by 2060 , even in the event of an expected increase in the fertility rate [9].

In this context, age diversity has been identified as one of the strategic capabilities that will add value to organizations over their competition [10]. Ageing population is a problem in all developed countries and has negative effects on the economic and social situation in the country. Therefore, it is necessary to deal with the diversity of the workforce in the organization. The world's increasing globalization requires more interaction among people from diverse backgrounds. People no longer live and work in an insular environment, they are now part of a worldwide economy competing within a global framework. For this reason, profit and non-profit organizations need to become more diversified to remain competitive. Maximizing and capitalizing on workplace diversity is an important issue for management. Supervisors and managers need to recognize how the workplace is changing and evolving. Managing diversity is a significant organizational challenge, so managerial skills must adapt to accommodate a multicultural work environment [11]. According to the Seemann et al. coaching courses are very important for managers as well as for the successful running of the organizations. They recommend managers in all areas of the business to attend the courses for developing coaching skills. It can bring a lot of positive changes e.g. regarding access to employees. Managers will be more interested in their 
employees, which will generate interest from employees [12]. Workforce diversity is a multi-faceted concept that will continue to evolve more industries to move toward a global marketplace. It also has proven to have led to a perception of being fundamental for employee performance. In the current scenario, employing a diversified workforce is a necessity for every organization but to manage such diversified workforce is also a big challenge for management. Workforce diversity is strength for the organization. If managed properly, it can increase productivity and thus the performance of the organization [11]. There are currently significant differences in the approach to various age groups in many fields of human activity. Due to the global demographic trend of increasing the age of the population and the growing number of people in the 50+ category, it is necessary to adopt measures that take age into account on the social level and also in the process of organizational management. These measures are collectively referred to as age management [13].

\subsubsection{Benefits of age management}

In connection with the ageing of the population, the length of working life is constantly increasing and thus affects not only employees but also employers themselves. The number of workers aged 50 and over is constantly increasing, while the number of workers under 50 is only slightly increasing or decreasing. Long-term human resource planning in the context of the ageing population is, therefore, essential to strengthen and maintain the competitiveness of organizations. The number of school leavers entering the labour market will not cover the needs of the labour market, therefore it will be necessary to employ older employees as well. In today's society, discrimination against employees' base on their age is present. If organizations do not take steps to implement an age management strategy now, consequences for them could be severe in the future. The age management process is long-term and it is important for all parts of society.

\subsubsection{Motivation in the context of age management}

In the field of motivation, employers are gradually changing their attitudes towards older workers because their motivation differs from younger employees. A motivated and satisfied workforce brings benefits not only to the organizations themselves in terms of higher performance, but also to the economy as a whole, and therefore age management is becoming increasingly important [7] [14]. The growing age diversity in organizations in most industrialized economies provides opportunities to motivate both older and younger workers by enabling them to benefit from each other through knowledge transfer [15]. The human resources of a company largely depend on how the company can respond to challenges of the market. Employers are recently trying to take care of their employees much more than just rewarding them with a salary. They provide them with a variety of employee benefits with which they try to motivate them to better work performance [16]. According to Kuzmin et al. the innovative development of human capital is a major factor in building a model of sustainable economic development in the context of globalization transformations, as it is formed through investment in human beings [17]. According to Urbancová et al., age management is becoming an increasingly important part of strategic human resources management practices and it can ultimately lead to a competitive advantage. Their results show that those organizations, focusing on the application of age management practices, achieved a competitive advantage regardless of size or sector of the organization [7]. The best organizations from all successful businesses are those that are attractive and active in caring for their employees. These organizations try to create the best possible conditions in the workplace. The success of an organization largely depends on the 
satisfaction of its employees. Such organizations can respond to the needs of the internal and external environment. In both environments they are transparent and they adapt to changes in demographic development [13].

\section{Methodology}

The purpose of this article is to compare the importance of motivational factors of different age groups of employees. The article focuses on employees of self-governing region offices in the Slovak Republic. It finds out which motivation factors affect employees in terms of their age and whether the factors are different in terms of age of employees. The primary research was carried out among employees of the self-governing region offices in Slovakia. The survey was conducted by a questioning method and four-level Likert scale was used, where 3 means very important and 0 means unimportant. To determine the importance of individual motivational factors, one of the questions from the questionnaire was aimed at evaluating the importance of 15 motivational attributes (variables). The questionnaire was sent to 824 employees and the number of received questionnaires was 123 .

The article aims to point out the option of identifying a reduced range of motivation attributes, which should the selected organization pay more attention in terms of the age of its employees. To reach this goal, in this article a multidimensional statistical method of factor analysis is used. According to Hanák, to be able to carry out an exploratory factor analysis, it is necessary to have a sufficient number of examining units in the selection. Normally, the minimum number of respondents to 1 question in the questionnaire is stated as 10 [18]. When performing the factor analysis for different age groups of employees, more than 10 answers were available for each age category. In order to perform a factor analysis, it is necessary to have a certain number of observations of each of the variables [19]. Factor analysis, by examining the interrelationships between variables, seeks to identify factors that are a reduction of the number of examined variables. In other words, factor analysis identifies those variables that are related to a smaller number of factors [18]. The search for factors is done by examining variables that can be assumed to be related to the sought factors. When correlating variables, a correlation matrix is obtained in which there are mutual correlations of all variables. These cross-correlations are the basis of the exploratory factor analysis. By examining these correlations, it is possible to find that some variables strongly correlate with each other and form a certain group. However, this group of strongly correlated variables usually only weakly correlates with other variables or with other groups of variables. A group of mutually correlated variables, and at the same time unrelated to another correlated group of variables, indicates the existence of a factor [18]. The rotation of factors is used to determine how the primary factors differ from each other and what variables are related to which factors. Several types of rotation can be used. Varimax rotation was used in the analysis for easier interpretation and wider application possibilities. Several methods can be used to extract the factors. The PSPP software uses principal component analysis and the principal axis factoring [18]. This software was also used for the purpose of fulfilling the goal of the article and thus also the implementation of factor analysis.

\section{RESULTS}

From the primary research, 13 variables (table 1) were identified. The second step of the research focused on finding out the reduced number of factors using factor analysis. The analysis was performed using PSPP open-source software. The software has been set to exclude all factors below 1 . Then, the Varimax rotation was set. This method is designed so 
that each variable fill only one factor, thus minimizing the number of variables that have a high charge [18]. Tables 2, 3, 4 and 5 represents the rotated component matrix for each age groups. The rotation of factors was used to determine how the primary factors differ from each other and what variables are related to which factors. Several types of rotation can be used.

Table 1. Identification of variables.

\begin{tabular}{|c|c|}
\hline \multicolumn{2}{|c|}{ Variables } \\
\hline Salary & Flexible working time \\
\hline Financial rewards & Recognition of personal results \\
\hline $13^{\text {th }}$ and $14^{\text {th }}$ salary \\
\hline $\begin{array}{c}\text { Supplementary } \\
\text { pension contributions }\end{array}$ & Advancement in career \\
\hline Added leave & Educational opportunity \\
\hline $\begin{array}{c}\text { Independence and } \\
\text { responsibility }\end{array}$ & Feel of the place \\
\cline { 2 - 2 } & Stability in employment \\
\hline
\end{tabular}

For the age group of up to 30 years, 5 factors were identified. The first factor represents financial motivation. The second factor can be called as a personal and career growth, the third factor can be described as benefit beyond the Labour Code, e.g. arising from Collective agreement. The fourth factor can be called as an atmosphere at the workplace and the fifth factor is flexibility and independence and employment activities.

Table 2. Rotated Component Matrix for the age group of up to 30 years.

\begin{tabular}{|c|c|c|c|c|c|}
\hline & \multicolumn{5}{|c|}{ Component } \\
\hline & 1. & 2. & 3. & 4. & 5. \\
\hline salary & .76 & -.15 & .17 & .03 & -.15 \\
\hline financial rewards & .93 & .25 & .02 & .06 & .21 \\
\hline $13^{\text {th }}$ and 14 ${ }^{\text {th }}$ salary & .93 & .07 & .01 & -.16 & .26 \\
\hline $\begin{array}{c}\text { supplementary pension } \\
\text { contributions }\end{array}$ & -.02 & .29 & .87 & .17 & .07 \\
\hline $\begin{array}{c}\text { added leave } \\
\text { independence and } \\
\text { responsibility }\end{array}$ & .26 & .13 & .86 & -.20 & -.17 \\
\hline flexible working time & .01 & .39 & .35 & -.49 & .47 \\
\hline recognition of personal results & -.09 & .67 & .12 & .17 & .31 \\
\hline advancement in career & .36 & .84 & .11 & .10 & -.05 \\
\hline
\end{tabular}




\begin{tabular}{|c|c|c|c|c|c|}
\hline educational opportunity & .07 & .75 & .30 & -.03 & -.15 \\
\hline feel of the place & -.02 & .21 & -.01 & .85 & .11 \\
\hline stability in employment & .03 & -.66 & .43 & .56 & .06 \\
\hline other benefits & .48 & -.08 & .56 & .09 & .71 \\
\hline
\end{tabular}

For the age group up to 40 years, 4 factors were identified. The first and second factors are the same as in the age group up to 30 years. The change occurs at the third and fourth factor. The third factor includes attributes such as supplementary pension contributions, stability, and other benefits. The fourth factor represents certain independence and responsibility and it is related to the atmosphere in the workplace. This is also related to the particular age of employees; added leave is usually offered to employees after a number of a particular age. Flexible working hours are not important enough for this age group of employees in terms of motivation.

Table 3. Rotated Component Matrix for the age group of up to 40 years.

\begin{tabular}{|c|c|c|c|c|}
\hline & \multicolumn{4}{|c|}{ Component } \\
\hline & 1. & 2. & 3. & 4. \\
\hline salary & .81 & -.01 & .15 & -.05 \\
\hline financial rewards & .90 & .09 & .03 & -.06 \\
\hline $13^{\text {th }}$ and 14 ${ }^{\text {th }}$ salary & .81 & -.13 & .02 & .12 \\
\hline $\begin{array}{c}\text { supplementary pension } \\
\text { contributions }\end{array}$ & .31 & -.10 & .63 & .01 \\
\hline added leave & .40 & -.25 & .46 & .59 \\
\hline $\begin{array}{c}\text { independence and } \\
\text { responsibility }\end{array}$ & -.12 & .11 & -.26 & .75 \\
\hline flexible working time & .08 & .29 & -.65 & .12 \\
\hline $\begin{array}{c}\text { recognition of personal } \\
\text { results }\end{array}$ & .12 & .71 & -.10 & .46 \\
\hline advancement in career & .00 & .80 & -.24 & -.03 \\
\hline educational opportunity & -.20 & .85 & .15 & .10 \\
\hline $\begin{array}{c}\text { feel of the place } \\
\text { ather benefits }\end{array}$ & .01 & .40 & .08 & .52 \\
\hline $\begin{array}{c}\text { stability in employment } \\
\text { other| }\end{array}$ & .26 & .35 & .52 & -.25 \\
\hline
\end{tabular}

For the age group of up to 50, 4 factors were identified. The first factor represents the seniority of the employee and includes variables such as independence and responsibility, recognition of personal results, advancement in career, and educational opportunities. The second factor is financial motivation, the third factor can be described as the atmosphere in 
the workplace. The fourth factor is certain independence associated with the possibility of a larger number of leave days and, with it, the possibility of participating in events.

Table 4. Rotated Component Matrix for age group of up to 50 years.

\begin{tabular}{|c|c|c|c|c|}
\hline & \multicolumn{5}{|c|}{ Component } \\
\hline & 1. & 2. & 3. & 4. \\
\hline salary & .08 & .84 & .11 & -.11 \\
\hline financial rewards & .16 & .83 & .05 & .29 \\
\hline $13^{\text {th }}$ and 14 ${ }^{\text {th }}$ salary & -.03 & .84 & -.04 & .23 \\
\hline $\begin{array}{c}\text { supplementary pension } \\
\text { contributions }\end{array}$ & .04 & .66 & .02 & .54 \\
\hline added leave & .01 & .21 & .22 & .81 \\
\hline $\begin{array}{c}\text { independence and } \\
\text { responsibility }\end{array}$ & .77 & -.07 & -.03 & .29 \\
\hline flexible working time & .52 & .10 & .12 & .59 \\
\hline $\begin{array}{c}\text { recognition of personal } \\
\text { results }\end{array}$ & .87 & .15 & -.17 & .27 \\
\hline advancement in career & .59 & .54 & .21 & -.12 \\
\hline educational opportunity & .86 & .08 & .27 & -.12 \\
\hline $\begin{array}{c}\text { feel of the place } \\
\text { stability in employment }\end{array}$ & .07 & -.10 & .87 & .20 \\
\hline other benefits & .46 & .23 & .80 & .15 \\
\hline
\end{tabular}

In the case of age group of over 50 years, 5 factors were identified. The first factor is related to the seniority and career status of the employees. The second factor contains variables such as supplementary pension contributions and flexible working time. Employees over 50 years want to spend time away from work. They are preparing to retire. This is the reason for the composition of the variables within the second factor. The third factor is related to financial motivation. The fourth factor represents employment stability. The fifth factor is related to other benefits such as added leave or events for employees.

Table 5. Rotated Component Matrix for age group of over 50 years.

\begin{tabular}{|c|c|c|c|c|c|}
\hline & \multicolumn{5}{|c|}{ Component } \\
\hline & 1. & 2. & 3. & 4. & 5. \\
\hline salary & -.43 & .49 & .58 & .16 & -.25 \\
\hline financial rewards & .08 & .02 & .77 & -.03 & .09 \\
\hline $13^{\text {th }}$ and $14^{\text {th }}$ salary & .31 & -.13 & .76 & -.08 & .23 \\
\hline
\end{tabular}




\begin{tabular}{|c|c|c|c|c|c|}
\hline $\begin{array}{c}\text { supplementary pension } \\
\text { contributions }\end{array}$ & .19 & .83 & .16 & .17 & .27 \\
\hline added leave & -.31 & .53 & .13 & .17 & .65 \\
\hline $\begin{array}{c}\text { independence and } \\
\text { responsibility }\end{array}$ & .08 & .15 & .24 & -.84 & .00 \\
\hline flexible working time & .08 & .85 & -.21 & -.21 & -.10 \\
\hline recognition of personal results & .92 & .05 & -.04 & .17 & -.03 \\
\hline advancement in career & .69 & .19 & .11 & .09 & .11 \\
\hline educational opportunity & .65 & .03 & .06 & -.08 & .56 \\
\hline feel of the place & .69 & -.10 & .26 & -.15 & .00 \\
\hline stability in employment & .28 & .29 & .35 & .69 & .13 \\
\hline other benefits & .16 & -.01 & .13 & .04 & .82 \\
\hline
\end{tabular}

Based on the obtained factors and on the basis of the answers obtained from the primary research, the value of significance of individual factors was quantified. The values of significance classify factors according to whether they are most significant or less significant. The results of the most significant factors for each age groups are shown in Table 6.

Table 6. Comparison of the most significant factors.

\begin{tabular}{|c|c|c|}
\hline Age group & $\begin{array}{c}\text { Value of } \\
\text { significance }\end{array}$ & Factor attributes \\
\hline \multirow{3}{*}{ up to 30} & \multirow{3}{*}{2.43} & independence and responsibility \\
\hline & & flexible working time \\
\hline & & other benefits \\
\hline \multirow{3}{*}{ up to 40} & \multirow{3}{*}{2.55} & salary \\
\hline & & financial rewards \\
\hline & & $13^{\text {th }}$ and $14^{\text {th }}$ salary \\
\hline \multirow{2}{*}{ up to 50} & \multirow{2}{*}{2.57} & feel of the place \\
\hline & & $\begin{array}{l}\text { stability in } \\
\text { employment }\end{array}$ \\
\hline \multirow{2}{*}{ over 50} & \multirow{2}{*}{2.45} & salary \\
\hline & & financial rewards \\
\hline
\end{tabular}




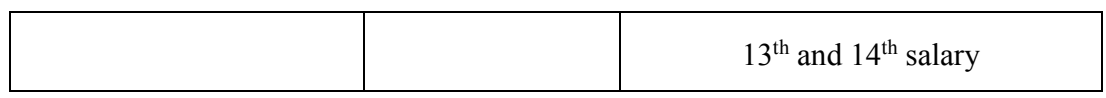

Results show that the most significant factor for the age group up to 30 years is independence, flexibility, responsibility and other employment benefits such as some cultural or sports activities. This age group is not simply motivated by monetary reward [20]. These employees want fulfilment and autonomy in their work [21] and they dislike being controlled [20]. The most significant factor for the age group up to 50 years is financial motivation. Older employees are facing the very real and very immediate financial issues associated with retirement and they are consciously and adaptively focusing on ensuring the quality of their retirement years [22].

\section{Discussions}

Based on a comparison of the most important factors for individual age groups, it was found that for the age group to 30 years, the most important factor is a flexible working environment with a sufficient degree of independence and responsibility. For age groups up to 40 years and over 50 years, it was found that these groups are motivated by financial motivation as the most significant factor. For the age group up to 50 years, the most important factor is a stable working environment. Age group under 30 (generation Z) are motivated by opportunities for advancement, while employees under 40 years (generation Y) are primarily motivated by more money [23]. The key to successful age management is a customized integrated strategy. To design an integrated age management strategy, a suitable approach to explore the organizational preconditions and the existing attitudes was applied [24]. It is equally important for employers to monitor employee satisfaction. Strenitzerová and Achimský, for example, deal with this issue, proposing a new perspective of employee satisfaction assessment that not only quantifies total satisfaction but identifies job attributes and socio-demographic characteristics affecting employee satisfaction and loyalty as a key concern for sustainable human resource management. Employee' satisfaction enhancement is critical for the firm's sustainability and is the base of the company's sustained competitive advantage [25]. This way of identifying the factors influencing the motivation of employees and determining their significance can be used in any organization, regardless of the sector of the economy.

VEGA 1/0152/18 Business models and platforms in digital space.

\section{References}

1. Šoltés, V., Repková Štofková, K., Kutaj, M. (2016). Education as a regional development aspect. In L. G. Chova, A. L. Martinez \& I. C. Torres (Eds.), EDULEARN16: Proceedings of the 8th International Conference on Education and New Learning Technologies (pp. 3643-3647). Barcelona: IATED-INT ASSOC TECHNOLOGY EDUCATION \& DEVELOPMENT.

2. Chinoracky, R., Corejova, T. (2019). Impact of Digital Technologies on Labor Market and the Transport Sector. In J. Bujnak \& M. Guagliano (Eds.), Proceedings of the $13^{\text {th }}$ International Scientific Conference on Sustainable, Modern and Safe Transport TRANSCOM 2019 (pp. 994-1001). Novy Smokovec: Transportation Research Procedia. 
3. Kaufman, E. (2016). Globalization and convergence-divergence of HRM across nations: New measures, explanatory theory, and non-standard predictions from bringing in economics. Human Resource Management Review, 26(4), 388-351.

4. Adiguzel, Z., Ozcinar, M.F., Karadal, H. (2020). Does servant leadership moderate the link between strategic human resource management on rule-breaking and job satisfaction? European Research on Management and Business Economics, 26(2020), 103-110.

5. Khan, A. A., Khan, M. A. (2019). Impact of Globalisation on Forma, Motivational and Strategic HRM Practices: AN Empirical Evidence from India. International Journal of Recent Technology and Engineering, 8(4), 3270-3276.

6. Mockaitis, A. I., Zander, L., De Cieri, H. (2018). The benefits of global teams for international organizations: HR implications. International Journal of Human Resource Management, 29(14), 2137-2158.

7. Urbancova, H., Vnouckova, L., Linhart, Z., Petru, G.J., Zuzak, R., Holeckova, L., Prostejovska, Z. (2020). Impact of Age Management on Sustainability in Czech Organisations. Sustainability, 12(3), 1064.

8. Sullivan, S.E., Al Ariss, A. (2019). Employment after Retirement: A Review and Framework for Future Research. Journal of Management, 45(1), 262-284.

9. Vaňo, B. (2019). Demographic challenges in Slovakia for the coming decades. Slovak statistics and demography, 2(2019), 5-13.

10. Darwin, J.R., (2014). Age diversity and its impact on employee performance in Singapore. International Journal of Research \& Development in Technology and Management Science, 21(5), 79-98.

11. Gowrishankar, K. L., Kanagaraj, N., Krishnan, S.G. (2017). Age diversity of the workforce and employees' performance - a descriptive study. International Journal of Marketing \& Financial Management, 5(10), 1-11.

12. Seemann, P., Stofkova, Z., Binasova, V. (2019). Developing coaching skills of managers in global context. In Kliestik, T. (Ed.), Sustainability in the globalknowledge economy: Proceedings of the $19^{\text {th }}$ International Scientific Conference Globalization and Its Socio-Economic Consequences 2019 (pp. 1-8). Zilina: University of Zilina.

13. Urbancová, H., Fajčíková, A. (2019). Organisational factors influencing the application of age management. Journal of Business and Retail Management Research, 14(1), 1-8.

14. Veth, N. K., Korzilius, H. P. L. M., Van der Heijden, J. M., Emans, B. J. M, De Lange, A. H. (2017). Which HRM practices enhance employee outcomes at work across the life-span? The International Journal of Human Resource Management, 30(19), 27772808.

15. Burmeister, A., Wang, M., Hirschi, A. (2020). Understanding the motivational benefits of knowledge transfer for older and younger workers in age-diverse coworker dyads: An actor-partner interdependence model. Journal of Applied Psychology, 105(7), 748459.

16. Stalmasekova, N., Genzorova, T., Corejova, T. (2017). Employee benefits as one of factors of work motivation. In P. Hajek, O. Vit, P. Basova, M. Krijt, H. Paszekova, O. Souckova \& R. Mudrik (Eds.), Innovations in science and education: Proceedings of the CBU International conference proceedings 2017 (pp. 448-452). Prague: Central Bohemia Univ. 
17. Kuzmin, O., Bublyk, M., Shakhno, A., Korolenko, O., Lashkum, H. (2020). Innovative development of human capital in the conditions of globalization. E3S Web of Conferences, 166, 13011.

18. Hanák, R. (2016). Dátová analýza pre sociálne vedy. Bratislava: Ekonóm.

19. Madleňáková, L., Turská, S., Madleňák, R. (2019). The image of the postal company as a key attribute of the customer's purchasing behaviour. In J. Bujnak \& M. Guagliano (Eds.), Proceedings of the $13^{\text {th }}$ International Scientific Conference on Sustainable, Modern and Safe Transport TRANSCOM 2019 (pp. 1088-1095). Novy Smokovec: Transportation Research Procedia

20. Mahmoud, A.B., Reisel, W.D., Grigoriou, N., Fuxman, L., Mohr, I. (2020). The reincarnation of work motivation: Millennials vs older generations. International Sociology, 35(4), 393-414.

21. Hill, A. (2017, May 9). Unrealistic expectations put millennials at risk of burnout. Financial Times. https://www.ft.com/content/be3289be-2c3e-11e7-bc4b-5528796fe35c

22. Cavanagh, T. M., Kraiger, K., Henry, K. L. (2020). Age-Related Changes on the Effects of Job Characteristics on Job Satisfaction: A Longitudinal Analysis. International Journal of Aging \& Human Development, 91(1), 60-84.

23. Schawbel, D. (2014, September 2). Gen Z Employees: The 5 Attributes You Need to Know. Entrepreneur EUROPE. https://www.entrepreneur.com/article/236560

24. Blomé, M.W., Borell, J., Håkansson, C., Nilsson, K. (2018). Attitudes toward elderly workers and perceptions of integrated age management practices. International Journal of Occupational Safety and Ergonomics, 26(1), 112-120.

25. Strenitzerová, M., Achimský, K. (2019). Employee Satisfaction and Loyalty as a Part of Sustainable Human Resource Management in Postal Sector. Sustainability, 11(17), 4591. 